\title{
O Evangelho New Age Sobre a gnose evangélica no Brasil na visão de seus detratores
}

\section{Airton Luiz Jungblut*}

Há no Brasil, já faz algum tempo, um coro de denunciantes a alertar para uma certa "nova-erização" de alguns setores do universo evangélico. Trata-se de acusações feitas, principalmente por teólogos mais ortodoxos, contra supostos desvios doutrinários oriundos dos Estados Unidos que estariam a estimular uma certa leitura gnóstica da relação crente-Deus. A conversão, segundo essa leitura, dizem os denunciantes, levaria o crente a reivindicar acesso irrestrito às bênçãos divinas o que, em muitos casos, significaria compartilhar dos poderes de Deus e, assim, tornar-se um "mini-Deus". Pretende-se através deste artigo, a análise destas acusações com o intuito de compreender as tensões e conflitos que se estabelecem entre a ortodoxia evangélica brasileira e alguns desses movimentos destradicionalizantes ("nova-erizantes") que estariam a introduzir os tais desvios gnósticos.

No intuito de bem analisar essa questão, julgo, contudo, apropriado realizar, inicialmente, um levantamento sobre alguns temas relacionados à questão da emergência de certas tendências gnósticas no interior da religiosidade

* Graduado em Ciências Sociais pela Pucrs, mestre e doutor em Antropologia Social pela Ufrgs. Atualmente atua como professor e pesquisador junto ao Programa de Pós-Graduação em Ciências Sociais da Pucrs. Tem desenvolvido nos últimos anos pesquisas sobre religião e Internet. Sobre esses temas publicou textos em revistas científicas e livros.

\begin{tabular}{|c|c|c|c|c|c|}
\hline Civitas & Porto Alegre & v. 6 & n. 2 & jul.-dez. 2006 & p. 101-121 \\
\hline
\end{tabular}


ocidental. Para tanto, será necessário atentar para alguns diagnósticos que têm sido feitos por alguns cientistas sociais, brasileiros e estrangeiros, sobre as características do fenômeno religioso no mundo ocidental contemporâneo. Assim sendo, iniciemos pelo diagnóstico feito por Colin Campbell de que estaríamos presenciando uma "orientalização" da religião ocidental.

$$
* * *
$$

A afirmação de Campbell de que estaria havendo uma orientalização do ocidente pode soar estranha em tempos em que se diagnostica uma "ocidentalização do mundo" como processo intrínseco ao fenômeno maior da globalização (cf. Ianni, 1995, p. 69-88). O autor, contudo, ciente do impacto e da aparente pouca plausibilidade de sua tese, vai logo dissipando qualquer malentendido ao afirmar:

Estou usando o termo "orientalização" para me referir a algo mais radical e mais amplo do que uma espécie de inversão do processo de "Coca-Cola-ização" [...]. Pois a tese aqui proposta é nada menos do que a afirmação de que o paradigma cultural ou teodicéia que tem sustentado a prática e o pensamento ocidental por cerca de dois mil anos está sofrendo um processo de substituição - e com toda probabilidade terá sido substituído, quando entrarmos no próximo milênio - pelo paradigma que tradicionalmente caracterizou o Oriente. Essa mudança radical tem sido, e continua sendo, ajudada pela introdução de idéias e influências do Oriente no Ocidente, mas o que tem sido de muito maior importância são os desenvolvimentos culturais e intelectuais dentro da própria civilização ocidental, desenvolvimentos que têm sido grandemente responsáveis por apressar essa mudança de paradigma (Campbell, 1997, p. 6).

Trata-se, pois, de um processo gradual de abandono da teodicéia ocidental e conseqüente adoção de uma teodicéia que, se não se processa simplesmente por incorporação de traços culturalmente difundidos do oriente, assemelha-se muito ao modelo oriental de teodicéia. Mas em que sentido? Basicamente pela substituição gradual da transcendência que caracteriza o espírito religioso do ocidente pela imanência que caracteriza, grosso modo, a religiosidade oriental. Segundo o que descreve Campbell, utilizando-se em parte das análises de Weber, uma situação de evidente diferença entre as teodicéias ocidental e oriental teria se mantido até pelo menos o século 18 quando, então, a situação no ocidente passa a se modificar no sentido de uma gradual inclinação para o modelo oriental. Campbell chama a atenção para o fato de que a partir desse momento a teodicéia calvinista - analisada por Weber, e 
que seria um dos modelos mais bem acabados de transcendalização de Deus na tradição judaico-cristã - estaria sofrendo ataques não somente das forças de secularização, como teria percebido Weber, mas também por "crenças alternativas" que, em sua essência, criaram as condições para a implantação de um modelo de teodicéia cada vez mais imanente e menos transcendente:

Essas [crenças], especialmente o Arminianismo, tenderam a enfatizar o amor mais do que a justiça terrível de Deus, a ponto de que homens e mulheres - como uma conseqüência de serem feitos "à Sua imagem" - eram também naturalmente bons e amáveis. Essa revolução na crença preparou o caminho para uma revolução ainda maior, representada pelo Romantismo, que rejeitou ao mesmo tempo as doutrinas literal e histórica do cristianismo, enquanto reteve uma crença tanto na bondade da humanidade como na espiritualidade que ligava a natureza do homem ao mundo natural. Todas essas crenças construíram os alicerces para a substituição da imagem transcendente do divino tradicionalmente ocidental pela imagem imanente oriental, um processo que, embora venha ocorrendo por cerca de duzentos anos, somente agora começa a se tornar de fato amplamente visível. Falar de "orientalização", portanto, não é, assim, discutir simplesmente a introdução de idéias e valores religiosos do Oriente; é referir-se ao processo pelo qual a concepção de divino tradicionalmente ocidental e suas relações com a humanidade e o mundo é substituída por aquela que tem predominado por longo tempo no Oriente (Campbell, 1997, p. 7).

Mas que transformações objetivas na religião ocidental ocorrem em função dessa troca de teodicéia de que fala Campbell? Já foi colocado que em essência isso implica mudar o modelo de ação divina no mundo de transcendente para imanente. Decorre disso uma quebra da dualidade homem-divindade que, de um modo geral, teria caracterizado por muito tempo a religião ocidental. O autor explicita algumas das conseqüentes implicações dessa "quebra de dualidade" fazendo uso da noção de "religião espiritual e mística" de Troeltsch. Dentre as crenças que podem compor essa modalidade de religião destaca-se, segundo Campbell, aquela que postula "que todos seres finitos têm sua existência em Deus, que é o fundamento da alma, a "semente" ou a "centelha" de todas as criaturas" e isso resultaria na seguinte situação:

Alguma forma de união com Deus (ou mais propriamente re-união) é, assim, a meta deste tipo de religião; uma meta que somente pode ser imaginada como a transformação da semente divina em um poder capaz de superar o mundo. Há assim, a crença numa "escala de espiritualidade" que atribui graus ao avanço da relação da alma com o divino; uma concepção que é necessariamente imanentista e 
nega o dualismo. Não há crença na oposição fundamental entre carne e espírito ou lei natural e milagre cristão; o que existe simplesmente são diferenças no grau em que o finito dista do divino. Conseqüentemente, evita-se o tom ascético, embora haja uma oposição ao egoísmo e materialismo do "mundo". De fato, é uma perspectiva que geralmente considera as preocupações seculares sem importância; ao mesmo tempo que, ao colocar a religião acima da ética, freqüentemente abraça o Antinomianismo e o Liberacionismo (Campbell, 1997, p. 11-12).

Ao se basear em uma inexistência de dualidade entre Deus e o homem esse tipo de religiosidade opera, então, com uma visão potencialmente divinizante do homem, já que a sua distância de Deus pode ser reparada, diminuída consideravelmente, neste mundo. Em outras palavras, é possível aqui tomar posse de algo do divino que nunca se teve ou que se perdeu em algum momento, estabelecer ou restabelecer uma ligação mais profunda com Deus neste mundo e com isso gradativamente investir-se de sua divinidade, compartilhar em algum grau da divindade de Deus, proceder uma "auto-deificação". Conseqüentemente, como chama a atenção Campbell, há uma relação menos marcada pelo ascetismo em relação ao mundo e também uma despreocupação ética. Todas as posturas que, como se pode ver, resultam em potencialização individual e isso, quer perante o divino (tornar-se semideus, auto-deificação), quer em relação ao "mundo" (não ter que se sujeitar a interdições ascéticas, estar acima da ética). Mas, prossigamos com a caracterização de Campbell:

Esta forma de religião é também sincrética. Por causa da sua rejeição ao dualismo e sua indiferença à verdade literal, uma religião espiritual e mística não leva necessariamente a uma posição de hostilidade em relação à cultura secular. Opõe-se firmemente ao materialismo e ao racionalismo e a uma mentalidade voltada para este mundo, mas tem uma afinidade com sistemas filosóficos idealistas e metafísicos. É também extremamente individualista, [...], normalmente não conduzindo à formação de organizações (Campbell, 1997, p. 12).

Como se vê novamente, trata-se de características que também remetem à potencialização ou autonomia individual já que, permitindo o sincretismo, os indivíduos ou os grupos religiosos que os congregam encontram-se mais livres da força coercitiva da tradição e podem lidar com os conteúdos de sua religiosidade de forma mais livre, permitindo o permanente ajuste aos interesses dos indivíduos ou grupos. Mas também porque existindo uma indiferença em relação à "verdade literal" há um conseqüente relativismo e com isso muitas áreas da cultura mundana já não precisam mais ser interditadas o que, certamente, 
dota o indivíduo de um repertório mais amplo de saberes e, conseqüentemente, mais autonomia de consciência. Por fim, como seria óbvio concluir, e Campbell arrola como característica, trata-se de uma forma de religiosidade "extremamente individualista" e que não se presta à "formação de organizações".

Ora, uma religião ou religiosidade com essas características, e que Campbel identifica como representante ideal-típico de uma "teodicéia oriental", mostra-se muito mais afinada com as tendências sócio-culturais da atualidade do que a sua correspondente ocidental. Isso fica evidente sobretudo em relação à forma como o indivíduo ganha autonomia na primeira. Campbell dá-se conta disso ao afirmar o seguinte:

[A] teodicéia oriental tem uma evidente vantagem sobre a ocidental tradicional na medida em que tanto é menos vulnerável ao ataque da ciência (visto que não é baseada em verdades literais, históricas) como é mais compatível com o pensamento moderno em sua aparente abertura e individualismo. Esse individualismo extremo, juntamente com o anti-dualismo e a relativização das pretensões de verdade, torna-a um alvo muito difícil para o ataque dos racionalistas e cientistas. De fato, a religião mística oriental tende a usar o ataque secular, humanístico sobre a religião tradicional em benefício próprio; ao mesmo tempo em que também se aproveita das incertezas e disputas no interior das ciências para promover afirmações místicas [...] (Campbell, 1997, p. 18).

Percebe-se, então, que além de afinar-se com uma inexorável tendência à potencialização do indivíduo em marcha no ocidente há alguns séculos e que, ao que tudo indica, se exacerba nos dias atuais, a "teodicéia oriental" cria condições bastante favoráveis para que a religião persista como uma necessidade sócio-cultural e/ou psicológica nas sociedades cada vez mais secularizadas e desencantadas da atualidade. Tornando a relação com o divino uma questão radicalmente interna, privada e, conjuntamente, valendo-se de um indivíduo que consegue não se importar ou não se angustiar com a real ou aparente desconexão das diversas esferas da realidade e subjetividade humanas (não separando rigidamente e/ou não percebendo como contraditórias entre si oposições como Deus/homem, carne/espírito, religioso/secular etc.), a "teodicéia oriental", de que fala Campbell, parece reunir todos os fatores de funcionalidade que permitem àquele tipo de religião ou religiosidade do qual essa teodicéia é base, coexistir sem grandes tensões com o mundo secularizado e desencantado. Assim sendo, a salvação da religião estaria no indivíduo? Não seria só no indivíduo ou só a partir do indivíduo que a religião teria 
condições de continuar existindo no mundo moderno? Algumas análises indicam a plausibilidade dessa hipótese.

Retomando o ponto que estava sendo desenvolvido, pode-se ainda acrescentar a contribuição de Otávio Velho a esse diagnóstico produzido por Campbell. Velho consegue perceber que essa diagnosticada tendência à adoção da "teodicéia oriental" no mundo moderno de que fala Campbell, a partir da noção de "religião espiritual e mística" de Troeltsch, fica mais enriquecida como tese se associada ao debate sobre uma possível "atualidade da gnose". Segundo Velho:

$[\ldots]$ certamente $[\ldots]$ algumas das características desse paradigma oriental - desde a renovada ênfase no fato de o ser humano ser feito à imagem de Deus, que por intermédio do arminianismo já contestara em seu próprio campo a afirmação calvinista da predestinação - tem afinidade com a gnose. Mas, certamente, trata-se de uma afinidade mais na direção do que aqui se denominou [...] gnose extensa [que ultrapassa os limites do humanismo]. E os anos 60 do nosso século marcariam o momento crucial dessa virada. Eis aí, portanto, mais um veio a percorrer: o da presença da gnose no que constituiria uma mudança radical do paradigma cultural do Ocidente (Velho, 1998, p. 46-47).

Velho, além de alertar para a natureza em grande parte gnóstica desse emergente paradigma cultural, nos chama a atenção para o fato de que redescobrir e enveredar pela gnose não significa ter que ir resgatá-la nas antigas tradições onde se encontram as formas históricas do gnosticismo já que ela reapareceria "sem a necessidade de uma transmissão direta" destas tradições. A gnose, segundo o autor, manifesta-se difusamente por toda parte, tende a emergir "de maneira selvagem e inovadora" e, por isso, seria como que um "produto de um "espírito de época"” (Velho, 1998, p. 47) que se estaria gestando no mundo comtemporâneo. $\mathrm{O}$ amplo quadro que Velho vislumbra das diversas manifestações atuais da gnose e que lhe autoriza a fazer esse diagnóstico é, em grande parte, fornecido pelas considerações de Harold Bloom. Segundo esse autor, que trata especificamente da religião norte-americana, o gnosticismo estaria entranhado, sem que para a maioria isso seja visível, no interior de praticamente todas as formas de religião americanas. Eis o quadro que o autor descreve:

[...] o gnosticismo está vivo e passando bem (talvez não tão bem) em nosso país, e não apenas nas paródias da Nova Era [...]. Nossos gnosticismos autênticos acham-se espalhados onde quer que nossos caudilhos republicanos sulistas ou do 
Oeste façam culto [...] e onde mais que espiras de templos mormons e Primeiras Igrejas Batistas perfurem os céus. Nossa Religião Americana, de fabricação caseira ou ostensivamente católica romana e protestante dominante, é mais um amalgama gnóstico que um tipo europeu de cristianismo histórico e doutrinal, embora muito poucos possam ver isso, ou talvez a maioria não queira ver. Alguns assustados padres católicos [...] tomaram consciência de seu perigo, e um punhado de ministros protestantes agora compreende que sua neo-ortodoxia está cedendo a um neognosticismo populista. Mas as grandes manifestações transcendem as igrejas, e são muito maiores até que as legiões de companheiros de viagem da Nova Era. Nossas indústrias em desenfreado florescimento de culto aos anjos, "experiências de quase morte" e astrologia - redes de adivinhação de sonhos - são versões em massa de um gnosticismo adulterado ou travestido (Bloom, 1996, p. 32).

A situação que Bloom descreve parece não se restringir exclusivamente ao campo religioso norte-americano, pois é possível, como se verá adiante, ver um quadro semelhante sendo detectado, por exemplo, por alguns observadores do universo evangélico brasileiro no interior dessa tradição e também por toda a sociedade de um modo geral. O que, como se vê, emerge de maneira dramática nesse processo em que, de diferentes formas, princípios difusos de gnosticismo se disseminam por todos os lados, é a situação de fragilidade em que se vêem as tradições religiosas mais ortodoxas, as tradições mais resistentes ao sincretismo. A disseminação da gnose, de uma religião imanentista, ou de uma "teodicéia oriental" - termos que, em essência, nomeiam uma mesma tendência que se vive hoje de busca, nas mais diversas tradições religiosas, de uma receita para a "auto-deificação" - não se faz sem que as tradições religiosas mais consolidadas e estáveis sofram, muitas vezes, reformulações consideráveis, e isso ocorre tanto para o júbilo dos que assim o desejam como para o desespero daqueles que vêem princípios, dogmas, confissões etc. de sua fé sendo relativizados, emendados por novas profecias atualizantes, ou, simplesmente, ajustados aos imperativos do "mercado".

Para nomear esse processo tem sido empregado, de um modo geral, o termo destradicionalização (cf. Velho, 1997; Fry, 1998; D’Andrea, 1996; Pedde, 1999), que, como se sabe, é utilizado para designar qualquer situação onde houve ou há um processo de declínio da tradição - religiosa ou não como norteadora do comportamento dos indivíduos ou dos grupos sociais. Mas, também tem havido o emprego de outros neologismos para tratar de aspectos mais precisos desse processo e que atingem especificamente as 
tradições religiosas, como, por exemplo, "desteologização" para nomear aquilo que estaria ocorrendo em muitas das formas de pentecostalismo, quando se passa a valorizar muito mais as experiências extáticas e o pragmatismo do que os argumentos teológicos (Velho, 1997, p. 56). Ou, ainda, termos como "nova-erização", criado por Anthony D'Andrea para nomear aqueles processos destradicionalizantes da religião que resultam para os grupos ou indivíduos neles envolvidos na adoção de práticas e cosmovisões afins com o que genericamente se conhece por "Movimento Nova Era" ou "New Age". Segundo D'Andrea:

Um sistema ou grupo é New Age, ou se transforma em New Age, se sofrer um processo de "nova-erização", ou seja, se incorporar, ou suscitar nos indivíduos, formas individualizantes (místicas, inner-directed) e reflexivistas (destradicionalizantes, contingencializantes e praxiológicas) (D'Andrea, 1996, p. 65).

A "nova-erização", segundo esse autor, atingiria até mesmo as religiões tradicionais num processo que favorece a autonomia individual na mesma proporção em que tende a tornar desnecessárias aquelas organizações especializadas na manutenção e perpetuação das tradições religiosas:

tomando-se a reflexividade institucional da modernidade (e o "individualismo reflexivo") enquanto processo condicionante (ainda que não determinante), é de se esperar que as grandes religiões, especialmente as ocidentais, se reflexivizem (isto é, se "nova-erizem"), assumindo formas de religiosidade destradicionalizadas, individualizadas e individualizantes, que tendem a se autonomizar de organizações eclesiais (D'Andrea, 1996, p. 307).

O que fica evidente, pelo que se examinou até aqui desses processos atuais pelo qual passa a religião ocidental contemporânea, seja qual for o termo empregado para nomeá-los e independente dos aspectos eleitos como fundamentais para compreendê-los, são os ganhos na esfera da autonomia individual, do poder individual.

Isso ocorre, em parte, como fruto das modificações na forma como passa a ser concebida a relação homem-Deus (reencantamento da religião, imanentismo, quebra da dualidade Deus-homem, gnose etc.), o que leva o indivíduo a conceber-se, através de exercícios subjetivos e internalizados, como detentor de uma divindade que não é mais exclusiva de um único Deus separado deste mundo. Essa pretensão ou esse exercício de "auto-deificação" que, pode-se dizer, não deixa de ser narcísico, certamente induz o indivíduo a um 
agir mais audacioso no mundo, pois tenderá ele a considerar sua vontade, já que divina, como imperiosa diante da realidade. Em outras palavras, dota-o de uma confiança psicológica diante do mundo, dota-o de um poder interno de auto-sugestão que efetivamente tem validade num mundo onde se atribui positividade à autoconfiança, à auto-estima, à coragem para a iniciativa audaciosa, à impetuosidade empresarial etc.

Em segundo lugar, a situação da religião atual gera ganho de poder ou autonomia para os indivíduos nela envolvidos pela verificada perda de importância atribuída ao papel das tradições religiosas decorrentes de fenômenos tais como o surgimento do pluralismo religioso e a conseqüente instauração de uma lógica de mercado religioso que se segue, o surgimento do espontaneísmo, da "desteologização", reflexivismo individual etc., mas também pelo enfraquecimento da capacidade congregacional e ético-coercitiva das comunidades religiosas tradicionais. Esse quadro faz realizar na esfera da religião aquelas mesmas autonomias individuais vigentes no mundo secular. Neste caso, contudo, trata-se de processos que diferentemente dos anteriores não se impõem em função de acontecimentos internos à esfera religiosa, mas, antes sim, em decorrência das diversas influências que a sociedade envolvente impõe à religião.

Há que se falar ainda de um poder obtido pelo indivíduo frente à religião que, embora esteja, em parte, implicado no processo geral de destradicionalização religiosa, merece aqui algumas considerações já que se trata de um aspecto importante dessa autonomia individual de que se está falando. Tratase do poder adquirido pelos indivíduos de comporem seus próprios sistemas religiosos de acordo com suas necessidades e preferências pessoais. Para melhor ilustrar esse tipo de autonomia é apropriado utilizar aqui uma caracterização feita por Pierre Sanchis do que ele considera "pós-moderno" em algumas formas de experiências religiosas da atualidade. Diz o autor:

Pós-moderno: uma construção eclética mais ainda do que um verdadeiro sincretismo, que recorta os universos simbólicos - o do seu grupo e os alheios, todos igualmente "virtuais" - e multiplica as "colagens", ao sabor de uma criatividade idiossincrática ("idiossincrética"...), radicalmente individual, mesmo se se articula em tribos de livre escolha (Sanchis, 1997, p. 104-105).

Sanchis é muito feliz ao sugerir o termo "idiossincrética" para definir esse tipo de colagem criativa "radicalmente individual" que caracteriza muitas 
das atuais atitudes dos indivíduos frente às tradições religiosas. Dito com outras palavras, o termo, ao nomear um tipo de produção idiossincrática de sincretismos religiosos, dá conta do que, efetivamente, se verifica em muitas formas de manifestações religiosas da atualidade. Nomeia com perspicácia não somente uma atitude normal nos dias de hoje de consumo diversificado e eclético de bens religiosos, que é característica de uma situação de mercado religioso (atitude que se vale de relativizações pragmáticas, tais como: "todos os caminhos levam a Deus"), como também, de forma mais evidente, o tipo de crenças características do que se chama de "Movimento Nova Era". Essas, como demonstra D'Andrea, ao serem produzidas e atualizadas por um ativo "reflexivismo individual", têm, quase que exclusivamente, no compósito produzido pelo indivíduo a única e efetiva - se é que se pode chamar assim unidade doutrinal verificável e, mesmo assim, sempre de uma forma aberta e provisória. A atitude "idiossincrética", sintetiza de certa forma uma manifestação extremada de autonomia individual ligada à destradicionalização religiosa, pois com ela já não se trata nem mais de escolher a que tradição religiosa se filiar e como permitir que ela interfira na vida do indivíduo e sim de escolher quais elementos de uma ou de mais tradições são válidos e úteis para o indivíduo e se harmonizam com sua personalidade ou temperamento religioso. Nesse processo, as tradições tendem a não serem percebidas pelo indivíduo como unidades indecomponíveis, mas, sim, como espécies de depósitos de onde é possível retirar "peças" sem que se precise levar tudo, o "kit" completo. Com a possibilidade de fazer uso de um idiossincretismo, o indivíduo, então, investe-se de uma autonomia frente às tradições religiosas análoga à que se utiliza para, por exemplo, escolher os itens que se quer ter disponíveis num computador que se pretenda comprar.

Como já se fez menção a áreas da religião tradicional que sofrem um processo de "nova-erização", a atitude "idiossincrética" começa a ser experimentada também ali onde a tradição sempre tendeu a se manter integral e ser relembrada, com alguma disciplina doutrinal, a partir de consensos coletivamente instituídos. Mas esse processo, como se verá a partir de agora, não ocorre livre de tensões. Iniciemos, pois o exame de alguns fatos atuais observados no meio evangélico brasileiro visando verificar como os diagnósticos acima desenvolvidos se relacionam, ou não, com essa importante área da religião e religiosidade brasileira. 
O forte crescimento dos grupos pentecostais no Brasil nestas últimas décadas, além de modificar a correlação de forças existentes entre as modalidades religiosas disponíveis no mercado religioso brasileiro - contribuindo até para uma possível perda do monopólio católico sobre este mercado -, modificou também, e de forma considerável, o repertório de crenças e doutrinas existentes no interior do que se pode chamar de campo evangélico brasileiro. Pode-se dizer que na mesma proporção em que o pentecostalismo assumia a vanguarda conversionista do campo evangélico, provocando um crescimento considerável no número de seus integrantes, fazia proliferar no seu interior uma série cada vez mais rica de novos discursos, profecias, crenças, percepções teológicas, doutrinas etc. numa verdadeira inflação de possibilidades de vivenciar, conforme gostos e afinidades pessoais, a fé cristã-evangélica. Neste sentido, pode-se, então, afirmar que o início de uma efetiva pluralização do campo religioso brasileiro com a emergência do pentecostalismo se fez de forma simultânea a uma pluralização interna do campo evangélico. O mais interessante dessa pluralização interna é que ela está relacionada não somente a um aumento considerável da diversidade denominacional, o que efetivamente ocorreu, mas também a uma diversidade de estilos e posturas religiosas que perpassa transversalmente as denominações. Em virtude disso, integrar uma determinada denominação evangélica não é hoje no Brasil, mais do que já foi no passado, índice seguro para a atribuição de um perfil individual preciso de posturas teológico-doutrinais.

Grande parte dessa diversidade interna do campo evangélico brasileiro, é preciso dizer, foi provocada e é alimentada por uma eficiente difusão de idéias teológicas e influências culturais evangélicas de origem norte-americana no rastro do crescimento do pentecostalismo. No Brasil é seguramente o crescimento do pentecostalismo que consolida uma eficiente onda de importações de influências evangélicas norte-americanas. O modelo de diversidade interna que aqui se presencia e que tem como base uma generalizada fragmentação de posturas e percepções teológico-doutrinais pode então ser creditado, em grande parte, a um transplante dessa situação feito dos Estados Unidos para o Brasil. Mas que posturas e percepções teológico-doutrinais são essas? Tomemos aquela que considero a mais impactante delas para um exame mais detalhado: a chamada "Teologia da Prosperidade".

Segundo o que conseguem demonstrar os intelectuais evangélicos que se dedicaram ao estudo dessa doutrina - e que normalmente a denunciam como 
herética em relação à ortodoxia evangélica - ela teria se gestado através de uma interessante cadeia de influências que se inicia fora da tradição evangélica com Phineas Quimby e chega aos grandes "profetas da prosperidade" como os pastores Kenneth Hagin e Kenneth Copeland, já no interior do campo evangélico norte-americano.

Quimby é o principal expoente de um movimento chamado "Novo Pensamento", que também está na gênese do "pensamento positivo" e da "autoajuda". Esse movimento, ocorrido em meados do século 19 nos EUA e que mormente é qualificado de "metafísico" - abrigando pesquisas nos campos do ocultismo, espiritismo, hipnose, parapsicologia etc. - postulava, entre outras coisas, que "o homem pode criar sua própria realidade através do poder da afirmação positiva" (Hanegraaff, 1996, p. 31). Ocorre que os ensinamentos "metafísicos" de Quimby teriam influenciado profundamente uma jovem senhora evangélica de nome Mary Baker - posteriormente Mary Baker Eddy - que, bastante interessada no poder da mente, mas também muito ligada aos ensinamentos cristãos-evangélicos, acabou por desenvolver a partir de pesquisas e escritos uma versão indisfarçavelmente gnóstica de cristianismo e fundar uma organização religiosa chamada "Ciência Cristã" para a difusão de suas idéias e a prática de curas através da mente. Segundo Mary Eddy, em livro intitulado "Ciência e saúde com a chave das escrituras" (uma espécie de Bíblia para os "cientistas cristãos"), "a realidade da Mente mostra de modo concludente como é que a matéria parece existir, mas não existe" (Eddy, 1995, p. 123).

Denunciados como heréticos pelas igrejas evangélicas nos EUA, os ensinamentos gnósticos da Ciência Cristã de Mary Eddy não deixaram de exercer influência, já no século 20, sobre um pregador evangélico independente, e teologicamente pouco ortodoxo, chamado Essek William Kenyon que, segundo alguns autores, é quem cria a base teológica da Teologia de Prosperidade. Além de ter sofrido influências de Mary Eddy, Kenyon esteve submetido ao clima "transcendental" do Emerson College de Boston, onde estudou. Este centro de estudos favoreceu, entre o final do século 19 e início do 20, o surgimento de uma série de "seitas metafísicas" que tinham em comum a idéia básica de que a mente, se treinada, pode desenvolver o poder de controlar e transformar a realidade física. Kenyon, tributário dessas influências, desenvolve, então, sua própria visão teológica do cristianismo, que conjuga a 
genérica crença cristã na redenção por meio de Cristo junto à crença "metafísica" de que a mente pode controlar a realidade.

Kenyon, apesar de ter tido algum sucesso como pregador independente num programa de rádio nos anos 1930, ao que tudo indica não conseguiu fazer com que suas idéias tivessem muito impacto no meio evangélico norteamericano. Isso pelo menos até que entrasse em cena o pastor pentecostal Kenneth Hagin, que passou a divulgar com muito sucesso em livros e pregações, já na segunda metade do século 20, idéias muito semelhantes as de Kenyon. Descobriu-se, posteriormente, que Hagin, que dizia conversar pessoalmente com Jesus e dele receber os ensinamentos que resultaram na formulação mais conhecida da Teologia da Prosperidade, na verdade havia plagiado extensivamente os ensinamentos de Kenyon. Chegou-se a descobrir em alguns dos livros mais importantes de Hagin, que defendiam os princípios básicos dessa doutrina, grandes extensões de texto que reproduziam palavra por palavra os escritos de Kenyon. Quando inquirido sobre esse fato, Hagin, segundo consta, nunca admitiu o plágio, preferindo sugerir que o Espírito Santo teria dito a ele, por inspiração, o mesmo que dissera a Kenyon.

O fato é que, valendo-se ou não de plágio, foi Hagin quem conseguiu fazer a Teologia da Prosperidade emergir a partir dos anos 1960 como uma importante doutrina no interior do protestantismo norte-americano, mais particularmente naquelas áreas do pentecostalismo ocupadas com a prática de "curas divinas". Seguiram a Hagin uma série de pregadores que adotaram os princípios de "sua" doutrina e deram prosseguimento à tarefa de desenvolvêla, agregando-lhe novos conteúdos. Nesse grupo de adeptos estão vários pregadores de sucesso como Kenneth Copeland (o nome mais importante depois de Hagin), Oral Roberts, T. L. Osborn, Pat Robertson, Robert Schuller, Jerry Falwell, Charles Capps, Fred Price, Benny Hinn, Paul Crouch, Jerry Savalle, Morris Cerrulo, Robert Tilton, Marilyn Hickey, Yonggi Cho etc. ${ }^{1}$

\footnotetext{
1 Quem desvendou a gênese da Teologia da Prosperidade foi o norte-americano Dan MacConnell em sua dissertação de mestrado intitulada $A$ diferent gospel. As informações ali levantadas ecoaram bastante no meio evangélico brasileiro e isso pode ser visto em uma série de livros que comentam as descobertas de MacConnell (cf. Pieratt, 1993; Gondim, 1994; Romeiro, 1996). No âmbito das Ciências Sociais brasileiras quem primeiro chamou atenção para essa gênese foi Ricardo Mariano (1995).
} 
Basicamente a Teologia da Prosperidade postula que todo cristão "nascido de novo" - ou seja, que teve uma experiência radical de conversão ao cristianismo - passa a dispor "legalmente" de todo o poder divino de Deus sobre o mundo. Esse direito teria sido obtido através da morte sacrificial de Jesus como forma de remição dos pecados humanos. Segundo Hagin, quando isso ocorreu "ressuscitamos com Cristo" de uma "morte espiritual", isto é, do estado de pecaminosidade sem perdão em que se encontrava a humanidade até então. Em função disso, os crentes estariam "assentados com Ele" ao lado direito do "trono de Deus", que é "o centro do poder do universo inteiro", e estando ali teriam o direito de compartilhar "não somente de Seu trono mas também de Sua autoridade" (Hagin, s.d., p. 24-25). Por serem "ressuscitados Nele", os crentes dividem com Jesus sua divindade, constituem o corpo do qual ele é a cabeça. Além disso, segundo Hagin, Jesus seria tão dependente dos crentes quanto estes são dele, pois para o mal (a doença, a pobreza, a infelicidade etc.) ser cotidianamente vencido no mundo e o efeito da ressurreição ser atualizado é preciso que isso seja ordenado pelos crentes "em nome de Jesus". Hagin exemplifica isso narrando fatos ocorridos numa das conversas pessoais que diz ter tido com Jesus. Durante essa conversa um demônio estaria presente fazendo estripulias e prejudicando a comunicação entre os dois e Hagin teria ficado intrigado pelo fato de Jesus não ter usado sua autoridade para repeli-lo. Depois de se cansar do tal demônio e da passividade de Jesus, Hagin tomou a iniciativa de "em nome de Jesus" ordenar a sua retira$\mathrm{da}$, o que se sucedeu prontamente. Indagando de Jesus sobre a sua passividade diante do demônio, ouviu dele que se sua retirada não fosse ordenada por Hagin ele não poderia realizá-la. Note-se que Hagin não busca legitimidade para "sua" visão teológica somente através de uma exegese bíblica, mas também recorre à sua "autoridade espiritual", que lhe possibilita ter revelações diretas e atualizadas de Deus.

No extremo dessa (teo)lógica, há entre seus defensores quem eventualmente afirme que os crentes que se encontram habilitados a exercerem sua "autoridade espiritual" não estão simplesmente agindo "através de Deus", mas investidos de divindade própria como se fossem eles próprios deuses. Hunt e McMahon, teólogos críticos da Teologia da Prosperidade, relacionam alguns dos pregadores dessa doutrina que dizem isso claramente:

Yonggi Cho, Charles Capps, e outros "mestres da fé" repetidamente falam do homem como um ser "do tipo Deus". Frederick K. C. Price, popular evange- 
lista de TV e pastor em Los Angeles, escreveu: "Creio que [...] Deus criou o homem como um deus. Um deus sob a autoridade de Deus". Charles Caps concorda: "[...] Jesus disse: Sois deuses. Em outras palavras, Adão era o deus da terra [...]. O homem foi criado [...], mas para ser deus sobre a terra [...]" Kenneth Copeland afirmou: "Você não tem um Deus vivendo em você; você é um deus!" Robert Tilton, pastor do Centro de Missões Mundiais Palavra da Fé, em Dallas, Texas, escreveu:

Você é [...] uma criatura do tipo Deus. Originalmente você foi criado para ser como que um Deus neste mundo.

O homem foi planejado ou criado por Deus para ser o deus deste mundo[...]. É claro, o homem perdeu esse domínio para Satanás, que se tornou o Deus deste mundo (Hunt e McMahon, 1995, p. 89).

Como se vê, a Teologia da Prosperidade conservou as características gnósticas presentes naquelas doutrinas que lhe são precursoras em seu desenvolvimento. Reivindicar poderes mágicos ou mentais sobre a realidade física e entender isso como inerente a uma natureza divina que se detém e precisa, por algum tipo de procedimento mental ou religioso, ser recuperada integralmente são ingredientes básicos de qualquer doutrina gnóstica. O que, porém, torna a Teologia da Prosperidade popular no universo evangélico parece não ser tanto os argumentos teológicos que lhe dão sustentação e suas características gnósticas, mas sim as receitas pragmáticas por ela produzidas para a resolução dos problemas do aqui e do agora. Os pregadores dessa doutrina que também é conhecida por "Movimento da Fé" ou "Confissão Positiva", têm sido prodigiosos em produzir verdadeiros manuais explicativos de como um crente "nascido de novo" deve proceder para que aquilo que deseja neste mundo se concretize como num passe de mágica.

Nesses "manuais", ou mesmo nas concorridas preleções que esses pregadores fazem em grandes auditórios ou ginásio de esportes (muitas delas pagas), ensina-se, entre outras coisas, que não é errado ao crente desejar a riqueza neste mundo já que, sendo filho de Deus e "ressuscitado em Jesus", que é "dono de todo ouro e de toda a prata", tem-se o direito de usufruir de todas as riquezas desse mundo. A pobreza, longe de ser percebida como algo positivo para a justificação dos cristãos, é apontada como maldição satânica que precisa ser "rejeitada em nome de Jesus", o mesmo valendo para a doença, a desarmonia conjugal e familiar, as crises existenciais, o insucesso profissional, o desajustamento social etc. Mas para obter riqueza, saúde, felicidade etc. neste mundo é preciso dominar os procedimentos adequados que 
permitam ao crente "tomar posse" dessas "bênçãos". Esses procedimentos geralmente incluem, segundo os pregadores e seus "manuais", tanto a atitude negativa de "rejeitar em nome de Jesus" as ações malignas de Satanás e seus demônios na vida do crente, como a atitude positiva de "tomar posse espiritualmente" de todas as "bênçãos" que Deus estaria obrigado a prover aos cristãos "nascidos de novo" a partir da morte sacrificial de Cristo. Chega-se até a aconselhar-se que o crente "ordene" ou "exija" o cumprimento imediato das prometidas "bênçãos". O uso das palavras corretas é tido como essencial nesses procedimentos, pois é preciso dizer de forma precisa e inequívoca o que se deseja e em nome de que "direitos adquiridos" se está solicitando que se cumpram. É também exigido do crente um trabalho de mentalização e de convencimento interno de que os desejos realmente são legítimos e serão efetivamente realizados. Em um livro com o sugestivo título de "O poder do desejo positivo", T. L. Osborn dá as seguintes "dicas":

O princípio de desejar as bênçãos de Deus até chegar à condição de requerê-las a fim de estar em perfeita forma diante de Deus, é vital para sua fé.

Crer para receber algo é desejá-lo. Ter fé para receber algo é requerê-lo.

Ao meditar sobre o poder positivo do desejo expressado na oração, escrevi a seguinte formula:

Prepare seu coração ao retratar mentalmente a bênção abundante de Deus.

Requeira essas bênçãos ao estender a mão para elas.

Aceite as idéias de Deus ao reivindicar Seu melhor.

Entregue seus tabus ao dizer "SIM" ao sonho de Deus.

Esvazie-se das influências negativas ao aceitar Seu suprimento ilimitado.

Receba Suas bênçãos ao relacionar-se com Seu plano.

Então você poderá transformar sua ORAÇÃO em testemunho triunfante para a glória de Deus.

Tenho PODER porque a Sua presença está em mim.

Sou RICO porque Seus recursos estão à minha disposição.

Tenho TUDO quanto preciso porque Ele está operando em mim.

Digo "SIM" a todos os sonhos de Deus, porque faço parte do plano dEle. 
Tenho ENERGIA porque Ele me revigora de dentro.

Estou RENOVADO porque vivo com Sua vida e compartilho do Seu propósito (Osborn, s.d., p. 139-40).

Percebe-se que há muita semelhança entre essa maneira de mentalização potencializadora do desejo proposto por Osborn e várias das fórmulas de mentalização utilizadas pela literatura de auto-ajuda para induzir o indivíduo a ter "motivações positivas", "autoconfiança", "ousadia para vencer" etc. Os termos "energia", "influência negativa", por sua vez, soam meio estranhos ao linguajar evangélico, estando mais afinados ao repertório lingüístico utilizado por adeptos das crenças do tipo "Nova Era". Essas, e outras semelhanças têm levado alguns dos críticos evangélicos a identificar a Teologia da Prosperidade como uma contaminação "Movimento Nova Era" no interior da cristandade protestante e a deflagrar um verdadeiro combate interno, no universo evangélico, contra o que passam a considerar uma perigosa apostasia maquinada por Satanás para desvirtuar uma grande parte do rebanho cristão de seu caminho de salvação. Costumam dizer que essa doutrina estimula nos crentes a mesma ambição que levou Lúcifer a decair: apoderar-se da divindade de Deus.

No Brasil, a Teologia da Prosperidade mostra-se presente de duas formas distintas no universo evangélico: como doutrina teológica central de algumas denominações e como crença difusa que pode ser assumida total ou parcialmente por indivíduos isolados, independentemente de serem aceitas ou não pelas denominações a que esses indivíduos pertençam.

No primeiro caso, trata-se de uma presença dessa doutrina em denominações (igrejas) que, praticamente de forma exclusiva, têm sido classificadas no Brasil como "neopentecostais" (cf. Oro, 1992; Mariano, 1995) ou - termo equivalente - pentecostais de "terceira onda" (Freston, 1994). Na verdade nessas caracterizações tipológicas a presença de práticas e discursos ligados à Teologia da Prosperidade é considerada necessária para se tomar por neopentecostal ou pentecostal de "terceira onda" uma determinada igreja ou denominação. Entre as igrejas que mais se destacam dentro dessa categoria estariam a Igreja de Nova Vida, a Igreja Universal do Reino de Deus, a Igreja Internacional da Graça de Deus, a Igreja Renascer em Cristo e a Comunidade Evangélica Sara Nossa Terra, denominações que surgem no Brasil principalmente a partir dos anos 70 e que tiveram considerável - em alguns casos, espantoso - crescimento, muito em função do sucesso "mercadológico" pro- 
duzido pelas sedutoras promessas amparadas na Teologia da Prosperidade, de enriquecimento econômico, cura para qualquer doença, felicidade etc. Em algumas dessas igrejas brasileiras fazem-se notar alterações autóctones na forma como essa doutrina é utilizada. Exemplo disso é a utilização de referências a entidades espirituais de religiões afro-brasileiras para nomear, com cores locais, os demônios que obstacularizariam a obtenção de "bênçãos" pelos crentes. Os exorcismos e "orações de rejeição" às interferências malignas são feitos, na maior parte do tempo, em referência a essas entidades. Outro aspecto autóctone é a ênfase acentuada que se dá nessas igrejas brasileiras à necessidade de o crente estar obrigado a fazer doações às igrejas para demonstrar sua fé a Deus e assim se habilitar a receber suas "bênçãos". Esse aspecto de "habilitação através da oferta", embora não totalmente ausente nos livros dos "profetas da prosperidade" norte-americanos, parece ser mais enfatizado pelos pregadores das igrejas neopentecostais locais do que o é nos Estados Unidos, merecendo inclusive livros que tratam especificamente deste assunto (cf. p. ex. Macedo, 1996).

Já no segundo caso, o da presença difusa e individualizada da crença na "(Teo)lógica" da Prosperidade no meio evangélico brasileiro, trata-se de um fenômeno que, por ser ambíguo, é difícil de ser avaliado em toda a sua extensão. É verificável, contudo, que um número expressivo de crentes evangélicos mesmo não estando vinculados às igrejas neopentecostais empregam em seus discursos, aberta ou implicitamente, pacífica ou relutantemente, partes ou a totalidade da argumentação teológica contida nessa doutrina para atribuir significados a determinadas práticas, percepções ou posturas experimentadas em seus cotidianos. E isso pode ocorrer até mesmo com crentes que congregam em igrejas que teologicamente se situam bem distantes das igrejas neopentecostais (igrejas históricas mais “desencantadas", por exemplo). Dessa forma, a Teologia da Prosperidade, mesmo que combatida ferrenhamente por críticos no interior do próprio universo evangélico, parece estar conseguindo através de adoções individualizadas e fragmentadas penetrar e se instalar silenciosamente ao menos naquela cultura evangélica que existe por cima das denominações e que é uma zona de difícil controle eclesiástico. Como uma lógica ou discurso alternativo que não precisa ser "comprado" integralmente, está adquirindo gradativamente um status de crença "positiva em alguns aspectos" e percebida como não totalmente contraditória para com as posturas teológicas e confissões mais tradicionais ("é tudo questão de 
ênfases" dizem alguns). A característica assumida por ela nesse processo de penetração difusa parece ser a de uma "mentalidade" mais do que de uma doutrina teológica estruturada e maciça. Certamente contribui para isso o fato de que a difusão da Teologia da Prosperidade fora da esfera neopentecostal se dá muito em função da literatura evangélica dedicada ao tema da obtenção da prosperidade. As livrarias evangélicas estão abarrotadas de livros sobre esse tema, sendo que alguns deles são verdadeiros best sellers e ocupam o topo dos livros evangélicos mais vendidos no Brasil nestes últimos tempos, segundo o que demonstra a pesquisa feita por Alexandre B. Fonseca (1998). Nessa mesma pesquisa fica também evidente o interesse por livros referentes à Teologia da Prosperidade por parte de evangélicos ligados a igrejas históricas que distam do pentecostalismo e do neopentecostalismo. Ocorre que esses livros são na maioria das vezes manuais que ensinam orações, mentalizações, procedimentos positivos a serem adotados no cotidiano para obter prosperidade, termos corretos a serem utilizados para a solicitação de "bênçãos" etc. e, tendo essas características, são lidos, na maioria das vezes, como se fossem manuais de auto-ajuda cristãos. E é dessa maneira pragmática, "desteologizada", que podem estar sendo absorvidos princípios da Teologia da Prosperidade. Além disso, como se tratam de livros, ou seja, produtos de consumo individual e que são lidos privadamente, a absorção dos conteúdos se dá longe do controle da congregação e do pastor, o que certamente contribui para uma menor cautela teológica e um maior "reflexivismo individual", uma maior liberdade de consciência em relação à "tradição". Talvez seja por essa razão que alguns pastores comecem a olhar com preocupação o grande crescimento verificado nos últimos anos do mercado editorial evangélico no Brasil (Romeiro, 1996, p. 44). É a possibilidade de muita informação religiosa ser consumida longe de seus olhos.

É preciso dizer, para finalizar, que a rápida descrição dessa Nova Era evangélica aqui esboçada deve tributos a visão dos seus detratores. São os teólogos evangélicos mais ortodoxos que percebem ou interpretam certas tendências doutrinárias recentes no interior do seu universo religioso como sendo de natureza gnóstica. O diagnóstico que fazem de que se trata de contaminação do movimento Nova Era equivale a uma acusação séria de apostasia para aqueles que enveredam por esses caminhos destradicionalizantes. Há que se relativizar, portanto, os diagnósticos produzidos por esses modernos inquisidores engajados que estão, na defesa da ortodoxia cristã-evangélica. 
Por outro lado, o que eles dizem não deve ser desconsiderado em sua capacidade de jogar luz sobre algumas das ameaças doutrinárias a ortodoxia evangélica que são sentidas na atualidade. É sempre possível aprender sobre as forças destradicionalizantes atuantes numa determinada modalidade religiosa atentando para o que dizem os legalistas doutrinários, os defensores da ortodoxia. Sempre se pode aprender algo com o que é revelado através do olhar de um perspicaz inquisidor. Carlo Guinzburg já nos havia alertado, em seu texto "O antropólogo como inquisidor", sobre o quanto se pode conhecer sobre a bruxaria da idade média olhando por cima dos ombros do inquisidor medieval (Ginzburg, 1991). A nova era evangélica que, aparentemente, tem tudo para ser considerada algo a mais que uma mera maledicência direcionada a grupos pentecostais menos ortodoxos, não nos teria sido noticiada se não fossem esses modernos inquisidores.

\section{Referências}

BLOOM, Harold. Presságios do milênio: anjos, sonhos e imortalidade. Rio de Janeiro: Objetiva, 1996.

CAMPBELL, Colin. A orientalização do Ocidente: reflexões sobre uma nova teodicéia para um novo milênio. Religião e Sociedade. v. 18, n. 1, p. 5-22, 1997.

D'ANDREA, Anthony A. F. O self perfeito e a nova era: individualismo e reflexividade em religiosidades pós-tradicionais. Dissertação (Mestrado em Sociologia) Programa de Pós-Graduação em Sociologia, Iuperj, Rio de Janeiro, 1996.

EDDY, Mary Baker. Ciência e saúde com a chave das escrituras. Boston: First Church of Christ Scientist, 1995.

FONSECA, Alexandre Brasil. Nova era evangélica, confissão positiva e o crescimento dos sem religião. VIII Jornadas sobre Alternativas Religiosas na América Latina. São Paulo, 1998.

FRESTON, Paul. Breve história do pentecostalismo brasileiro. In: ANTONIAZZI, A. et al. (Org.). Nem anjos nem demônios: interpretações sociológicas do pentecostalismo. Petrópolis: Vozes, 1994. p. 67-159.

FRY, Peter. Religião e destradicionalização na África Austral. VIII Jornadas sobre Alternativas Religiosas na América Latina. São Paulo, 1998.

GINZBURG, Carlo. O inquisidor como antropólogo. Revista Brasileira de História, São Paulo. v. 1, n. 21, p. 9-20, 1991

GONDIM, Ricardo. $O$ evangelho da nova era: uma análise e refutação da chamada teologia da prosperidade. São Paulo: Press Abba, 1994. 
HAGIN, Kenneth. A autoridade do crente. Rio de Janeiro: Graça Editorial, s.d.

HANEGRAAFF, Hank. Cristianismo em crise. Rio de Janeiro: Casa Publicadora das Assembléias de Deus, 1996.

HUNT, Dave e McMAHON, T. A. A sedução do cristianismo: discernimento espiritual nos últimos dias. Porto Alegre: Chamada da Meia-Noite, 1995.

IANNI, Otavio. A sociedade global. Rio de Janeiro: Civilização Brasileira, 1995.

MACEDO, Edir. O perfeito sacrificio: o significado espiritual do dízimo e ofertas. Rio de Janeiro: Editora Gráfica Universal, 1996.

MARIANO, Ricardo. Neopentecostalismo: os pentecostais estão mudando. Dissertação (Mestrado em Sociologia) - Departamento de Sociologia da Faculdade de Filosofia, Letras e Ciências Humanas da USP, São Paulo, 1995.

ORO, Ari Pedro. "Podem passar a sacolinha": um estudo sobre as representações do dinheiro no neopentecostalismo brasileiro. Cadernos de Antropologia, Porto Alegre, n. 9, p. 7-44, 1992.

OSBORN, T. L. O poder do desejo positivo. Rio de Janeiro: Graça Editorial, s.d.

PEDDE, Valdir. Destradicionalização: uma perspectiva para o entendimento do fenômeno carismático nas igrejas históricas. IX Congresso Brasileiro de Sociologia, Porto Alegre, 1999.

PIERATT, Alan B. O evangelho da prosperidade: análise e resposta. São Paulo: Vida Nova, 1993.

ROMEIRO, Paulo. Evangélicos em crise: decadência doutrinária na igreja brasileira. São Paulo: Mundo Cristão, 1996.

SANCHIS, Pierre. O campo religioso contemporâneo no Brasil. In: ORO, A. P.; STEIL, C. A. (Orgs.) Globalização e religião. Petrópolis: Vozes, 1997. p. 103-116.

VELHO, Otávio. Globalização: antropologia e religião. In: ORO, A. P.; STEIL, C. A. (Orgs.) Globalização e religião. Petrópolis: Vozes, 1997. p. 43-62.

. Ensaio herético sobre a atualidade da gnose. Horizontes Antropológicos, Porto Alegre, n. 8, p. 34-52, 1998.

Recebido em 8 de agosto de 2006 e aprovado em 4 de setembro de 2006 